\begin{tabular}{|c|c|c|}
\hline & $\begin{array}{c}\text { International Journal of Current Research in } \\
\text { Biosciences and Plant Biology } \\
\text { EXCELLENT } \\
\text { PUBLISHERS }\end{array}$ \\
Volume $4 \bullet$ Number 7 (June-2017) $\bullet$ ISSN: 2349-8080 (Online) \\
Journal homepage: www.ijcrbp.com
\end{tabular}

\title{
High Frequency of Plant Regeneration through Adventitious Shoots Proliferation from Leaf Explant of Patchouli-Pogostemon cablin (Blanco) Benth.
}

\author{
C. Gopi* \\ Department of Botany, Cardamom Planters' Association College, Bodinayakanur - 625 513, Tamil Nadu, India \\ *Corresponding author.
}

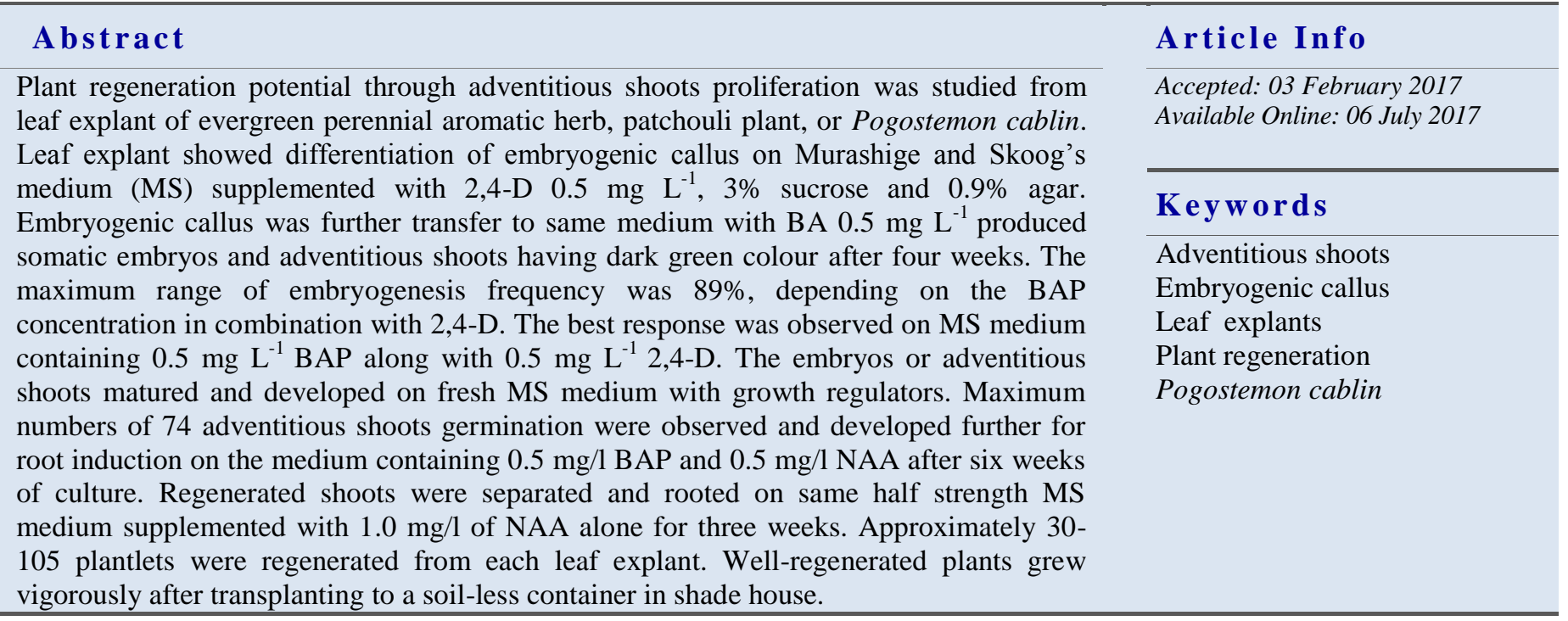

\section{Introduction}

Pogostemon cablin (Blanco) Benth. is commonly called as patchouli belongs to Lamiaceae, evergreen perennial aromatic plant native to tropical countries like Indonesia, the Philippines, Malaysia, India, China, Seychelles, and Brazil. The oil is extracted from patchouli plant used in various purposes like perfumery, cosmetics, incense, insecticides, food flavoring (Xiao, 2001). Pogostemon sp has been used traditionally in
Indian system of medicine and Chinese medicine to treat various diseases such as acne, eczema, inflamed, cracked or mature skin, dandruff, athlete's foot, varicose veins, hemorrhoids, impetigo and also been used for nervousness, depression, insomnia, and aphrodisiac (Kageyama et al., 1995; Misra, 1996; Xiao, 2001).

In most of plant species, regeneration of plants from callus tissue, especially highly totipotent embryogenic callus, has been recognized as one of the essential 
techniques for micropropagation and biotechnological applications (Tokuhara and Mii, 2001). Therefore, the interest in using these techniques for rapid and largescale propagation of medicinal and aromatic plants has been significantly increased (Sahoo et al., 1997; Gopi et al., 2006). However, there have been no much reports on the induction of embryogenesis and adventitious shoots proliferation for plant regeneration in this species. Many in vitro studies have been conducted for this plant using nodal and leaf explant for regeneration through callus (Kageyama, 1995; Misra, 1996; Xiao et al., 2001). Some of previous work on Lamiaceae species, including the Ocimum genus, using different explants, like nodal segments (Ahuja et al., 1982; Shahzad and Siddiqui, 2000; Begum et al., 2000; Gopi et al., 2006), leaf explants (Phippen and Simon, 2000; Gopi and Ponmurugan, 2006), young inflorescence (Singh and Sehgal, 1999) and axillary buds (Begum et al., 2000, 2002).

In the present study, we show the successful results on high frquency of plant regeneration through adventitious shoots proliferation from leaf explant of herbal spice patchouli - Pogostemon cablin (Blanco) Benth.

\section{Materials and methods}

For in vitro study on Pogostemon cablin (Patchouli), the experimental plant was grown in our medicinal plant garden. Young leaf explants from healthy plant were collected and washed in running tap water for approximately an hour. After surface sterilization of explants with $70 \%$ ethanol for $20-30$ s followed by $0.05 \%$ mercuric chloride treatment for 5-7 min were washed in double distilled water for five times. The trimmed explants were cultured on $0.9 \%$ agar gelled Murashige and Skoog's (MS) (1962) basal medium supplemented plant growth regulators with $3 \%$ sucrose. In this study, different concentrations ( 0.25 to $\left.4.0 \mathrm{mg} \mathrm{l}^{-1}\right)$ of plant growth regulators such as 2,4-dichlorophenoxy acetic acid (2,4-D), 6- benzylamino purine (BAP), and $\alpha$-naphthalene acetic acid (NAA) alone/in combinations were used for establishments of adventitious shoots and complete plant regeneration with shoots and roots. The $\mathrm{pH}$ of the culture media was adjusted to $5.7 \pm 0.1$ before addition of agar and sterilized to by autoclaving for 20 min under $1.1-\mathrm{kg} / \mathrm{cm}^{2}$ pressure at $121^{\circ} \mathrm{C}$. Cultures were maintained in the culture room at $25 \pm 1^{\circ} \mathrm{C}$ with light intensity of 2000-3000 lux provided by cool white fluorescent light for $16 \mathrm{hrs}$ photoperiod and 70-75\% relative humidity. All the treatments were replicated thrice with 20 culture bottles in each set. The percentage of adventitious buds responses and number of shoots developments were recorded and analyzed statistically.

\section{Results and discussion}

The chemical Initial studies on young leaf explants culture in MS medium supplemented with 2,4-D at different concentration was used and showed notable responses within four weeks of incubation (Table 1). White colour globular structured embryogenic callus was observed at $0.5 \mathrm{mgl}^{-1}$ with $89 \%$ of responses among tested concentration (Fig. 1a-b). As earlier reports, 2,4-D has the ability to induce the embryogenic potential from leaf explants (Pola and Mani, 2006). This globular embryogenic callus was further sub cultured in above MS medium additionally supplemented with BAP at different concentration for further establishment of embryogenesis (Table 1).

Table 1. Effect of different concentration of 2,4-D and BA on MS medium for induction of somatic embryogenic callus from leaf explant of Pogostemon cablin (Blanco) Benth.

\begin{tabular}{|c|c|c|c|}
\hline $\begin{array}{l}\text { Concentration of PGRs } \\
\left(\mathrm{mg} \mathrm{l}^{-1}\right) \text { in MS medium }\end{array}$ & Percentage of responses & $\begin{array}{l}\text { Embryogenic callus } \\
\text { responses }\end{array}$ & Morphology of responses \\
\hline $2,4-\mathrm{D}(0.25)$ & 78.6 & + & Pale yellow \\
\hline $2,4-\mathrm{D}(0.50)$ & 89.0 & +++ & Pale yellow \\
\hline $2,4-\mathrm{D}(1.00)$ & 84.9 & +++ & Pale yellow \\
\hline $2,4-\mathrm{D}(2.00)$ & 72.2 & ++ & Pale yellow \\
\hline $2,4-\mathrm{D}(4.00)$ & 22.6 & + & Pale brown \\
\hline $2,4-\mathrm{D}(0.5)+\mathrm{BAP}(0.25)$ & 65.2 & ++ & yellowish green \\
\hline $2,4-\mathrm{D}(0.5)+\mathrm{BAP}(0.50)$ & 70.3 & ++ & Pale green \\
\hline $2,4-\mathrm{D}(0.5)+\mathrm{BAP}(1.00)$ & 68.6 & ++ & Green \\
\hline $2,4-\mathrm{D}(0.5)+\mathrm{BAP}(2.00)$ & 43.2 & + & Green \\
\hline $2,4-\mathrm{D}(0.5)+\mathrm{BAP}(4.00)$ & 20.8 & - & - \\
\hline
\end{tabular}

15 explants were maintained in each treatment and data (SE) recorded up to five weeks of culture.

+ Embryogenic callus responses. 

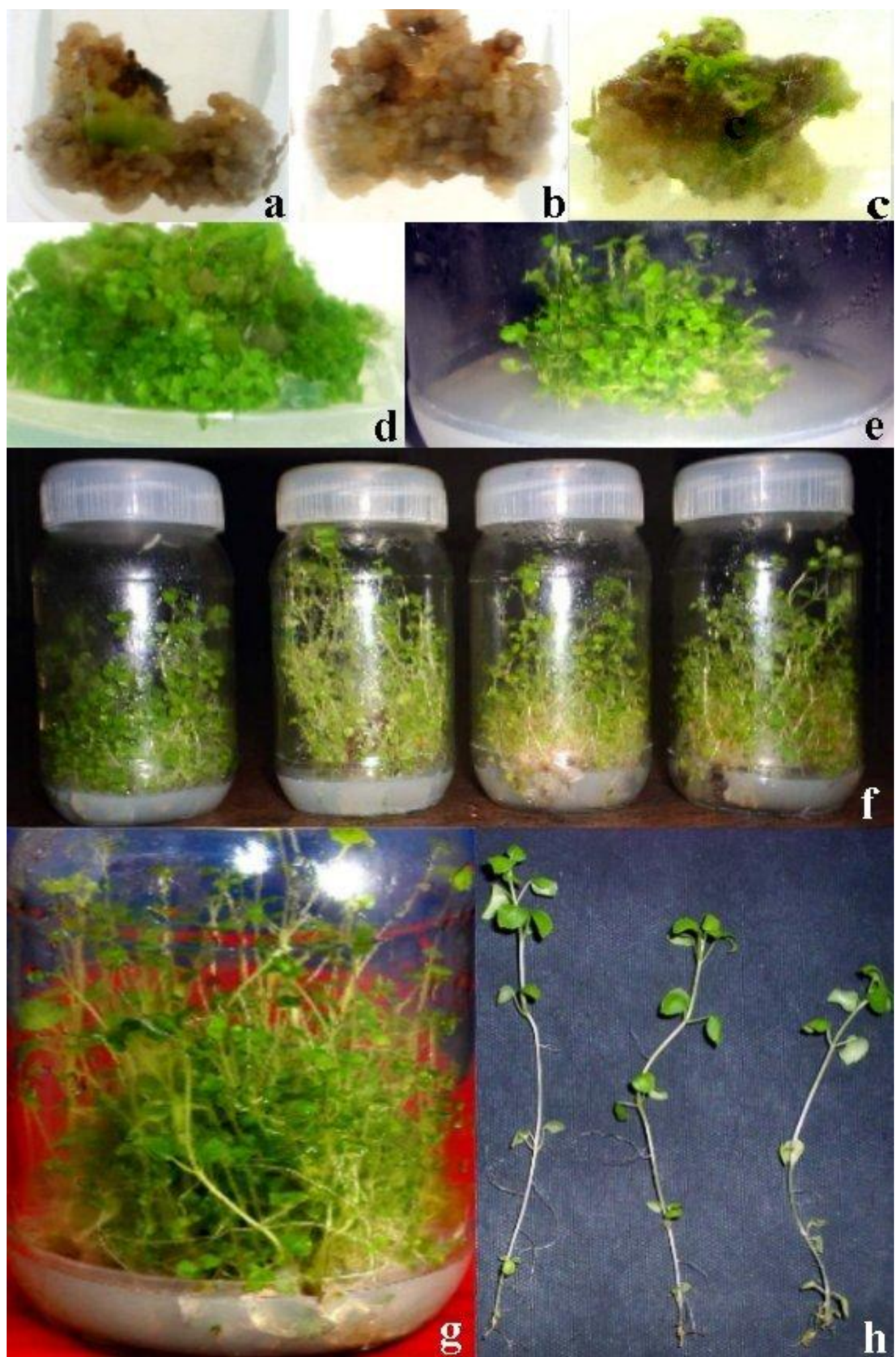

Fig. 1: In vitro studies on establishment of adventitious shootsand plantlet development from leaf explant of Pogostemon cablin (Blanco) Benth.; (a-b) Induction of embryogenic callus from leaf explant on MS medium with 2,4-D (0.5 mg/l); (c-d) Formation of dark-green embryogenic callus and adventitious buds of shoots on MS medium with 2,4-D $\left(0.5 \mathrm{mgl}^{-1}\right)$ and BAP $(0.5 \mathrm{mg} / \mathrm{l})$; (e-f) Plantlets regenerated through adventitious shoots on MS medium with BAP $(0.5 \mathrm{mg} / \mathrm{l})$ and NAA $\left(0.5 \mathrm{mgl}^{-1}\right) ;(\mathrm{g}-\mathrm{h})$ Complete Plant regeneration with rooting after four weeks of culture on MS medium with BAP $(0.5 \mathrm{mg} / \mathrm{l})$ and NAA $\left(1.0 \mathrm{mgl}^{-1}\right)$ 
The embryogenesis efficiency was significantly increased in $0.5 \mathrm{mg} / \mathrm{l} \mathrm{BAP}$ with green colour shoots germinations (Fig. 1c). BAP in combination with 2,4-D had remarkable responses towards effective embryogenesis and shoot proliferation as previous reports (Kintzios et al., 1999; Kim et al., 2004; Karun et al., 2004; Gopi and Ponmurugan, 2006). In higher concentration of BAP found to be inefficient for shoot establishment. This result shows that low concentration of $(0.5 \mathrm{mg} / \mathrm{l}) \mathrm{BAP}$ is enough to develop the multiple shoots regeneration whereas, Misra (1996) reported that BAP at $1.0 \mathrm{mgl}^{-1}$. These green embryogenic calli were sub-cultured to establish high frequency of plant regeneration in MS medium supplemented with BAP combination with NAA at different concentration (see Table 2).

Table 2. Effects of BAP in combination with different concentration of NAA on plant let regeneration, elongation and root induction of somatic embryos of Pogostemon cablin (Blanco) Benth.

\begin{tabular}{lllll}
\hline $\begin{array}{l}\text { Combination of PGRs } \\
\left(\mathbf{m g ~ l}^{-\mathbf{1}}\right) \text { in MS medium }\end{array}$ & Number of shoots/culture & $\begin{array}{l}\text { Length of } \\
\text { shoots }(\mathbf{c m})\end{array}$ & $\begin{array}{l}\text { Intensity of } \\
\text { Rooting responses }\end{array}$ \\
\hline BA (0.25) & NAA (0.25) & $43.4 \pm 0.272$ & $9.10 \pm 0.36$ & + \\
& NAA (0.50) & $58.8 \pm 0.645$ & $9.28 \pm 0.52$ & + \\
& NAA (1.00) & $50.4 \pm 0.489$ & $8.90 \pm 0.41$ & ++ \\
& NAA (2.00) & $24.3 \pm 0.254$ & $5.78 \pm 0.41$ & +++ \\
BA $(0.50)$ & NAA (4.00) & $19.2 \pm 0.178$ & $4.70 \pm 0.41$ & ++ \\
& NAA (0.25) & $69.3 \pm 0.145$ & $10.60 \pm 0.66$ & + \\
& NAA (0.50) & $74.8 \pm 0.654$ & $10.50 \pm 0.62$ & ++ \\
& NAA (1.00) & $70.4 \pm 0.143$ & $9.89 \pm 0.48$ & ++ \\
BA $(1.00)$ & NAA (2.00) & $66.3 \pm 0.478$ & $7.80 \pm 0.29$ & ++ \\
& NAA (4.00) & $19.6 \pm 0.258$ & $5.12 \pm 0.52$ & ++ \\
& NAA (0.25) & $62.20 \pm 0.485$ & $12.28 \pm 0.35$ & + \\
& NAA (0.50) & $68.38 \pm 0.251$ & $12.32 \pm 0.42$ & ++ \\
& NAA (1.00) & $68.19 \pm 0.462$ & $10.09 \pm 0.58$ & ++ \\
& NAA (2.00) & $58.32 \pm 0.458$ & $9.23 \pm 0.25$ & ++ \\
\hline
\end{tabular}

15 cultures were maintained in each treatment and data (SE) recorded up to five weeks of culture; + Rooting response.

Ocimum sanctum belongs to this family has been reported by Singh and Sehgal (1999) that BAP alone is required for plant regeneration. The maximum number of shoots induction of per culture 74.80 was achieved from medium supplemented with $0.5 \mathrm{mg} / \mathrm{l} \mathrm{BAP}$ and 0.5 mg/l NAA, in four weeks (Fig. 1c-f). Mao et al. (1995) and Espinosa et al. (2006) reported that BAP proved superior to other cytokinins for multiple shoot induction of Clerodendrum colebrookianum.

Normally, Pogostemon cablin shows good response towards plant regeneration in MS medium in the presence of BAP combined with NAA as earlier reports (Hu et al., 2005; Misra, 1996; Kageyama et al., 1995). Several authors have observed a strong co-relation between the auxins and cytokines ratio in the media and shoot formation using different explant sources and genotypes (Pattnaik and Chand, 1996; Reddy et al., 2001; Dode et al., 2003; Khanna and Raina, 1998; Sugimura et al., 2005; Singh and Sehgal, 1999; Shahzad and Siddiqui, 2000; Gopi and Ponmurugan, 2006).

Shoot elongation higher while BAP along with NAA combination at different concentration. While BAP at $0.5 \mathrm{mgl}^{-1}$ combination with NAA at $0.5 \mathrm{mgl}^{-1}$ showed maximum number of shoot germination occurred simultaneously shoot elongation was able to achieve about $10 \mathrm{~cm}$ length with remarkable rooting response (see Table 2). Similarly high concentration of BAP at $1.0 \mathrm{mgl}^{-1}$ showed good elongation of shoots about 12 $\mathrm{cm}$. After 3 to 4 weeks, when regenerated shoots reached a length of more than $8 \mathrm{~cm}$, they were separated and planted on half strength MS basal medium with and without NAA. In cultures, where the shoots were inoculated on auxins free basal medium, no root formation was observed. Whereas root primordial emerged from the shoot base on first week of culture on NAA supplemented medium.

This study supports the rapid multiplication through adventitious buds of leaf explant of this useful medicinal plant by in vitro conditions. Multiple shoots and complete plant regeneration can be easily derived from leaf cultures on 2,4-D, BAP and NAA containing MS medium. This approach offers a means for producing maximum plant regeneration from leaf explants of 
Pogostemon cablin. Thus, desirable genotypes can be regenerated in large numbers within a short period. It may be ideal for genetic transformation because of the high frequency of plant regeneration and ready availability of explants throughout the year. It may also be useful for inducing genetic variability through e.g. mutagenesis and somaclonal variation. Further studies into the transfer of germinated somatic embryos to ex vitro conditions are needed.

\section{Conflict of interest statement}

Authors declare that they have no conflict of interest.

\section{Acknowledgement}

The author acknowledges Department of Biotechnology, KSRCT, Tiruchengode and the Department of Botany, Cardamom Planters' Association College, Bodinayakanur - 625 513, Tamil Nadu, India, for providing necessary facilities.

\section{References}

Ahuja, A., Verma, M., Grewal, S., 1982. Clonal propagation of Ocimum species by tissue culture. Ind. J. Exp. Biol. 20, 455-458.

Begum, F., Amin, M.N., Azad, M.A.K. In vitro clonal propagation of holy basil (Ocimum sanctum L.). Plant Tiss. Cult. 10(1), 31-37.

Dode, L. B., Bobrowski, V. L., Braga, E. J. B., Seixas, F. K., Schuch, M. W., 2003. In vitro propagation of Ocimum basilicum L. (Lamiaceae), Acta Scient. Biol. Sci. 25(2), 435-437.

Espinosa, A. C., Pijut, P. M., Michler, C.H., 2006. Adventitious shoot regeneration and rooting of Prunus serotina in vitro cultures. HortSci. 41(1), 193-201.

Gopi, C., Ponmurugan, P., 2006. Somatic embryogenesis and plant regeneration from leaf callus of Ocimum basilicum L. J. Biotechnol. 126(2), 260-264.

Gopi, C., Sekhar, Y.N., Ponmurugan, P., 2006. In vitro multiplication of Ocimum gratissimum L.. Afr. J. Biotech. 5(9), 723-726.

Gopi, C., Vatsala, T.M., Ponmurugan, P., 2006. In vitro multiple shoot proliferation and plant regeneration of Vanilla planifolia Andr. - A commercial spicy orchid. J. Plant Biotechnol. 8(1), 37-41.

Hu, J.B., Liu, J., Yan, H.B., Xie, C.H., 2005. Histological observations of morphogenesis in petiole derived callus of Amorphophallus rivieri Durieu in vitro. Plant Cell Rep. 24(11), 642-648.

Kageyama, Y., Honda, Y., Sugimura, Y., 1995. Plant regeneration from patchouli protoplasts encapsulated in alginate beads. Plant Cell Tiss. Organ Cult. 41(1), 65-70.

Karun, A., Siril, E. A., Radha, E., Parthasarathy, V. A., 2004. Somatic embryogenesis and plant regeneration from leaf and inflorescence explants of arecanut (Areca catechu L.). Curr. Sci. 86(12), 1623-1628.

Khanna, H.K., Raina, S.K., 1998. Genotype $\times$ culture media interaction effects on regeneration response of three indica rice cultivars. Plant Cell Tiss. Organ Cult. 52, 145-153.

Kim, S. W., 2004. High frequency somatic embryogenesis and plant regeneration in petiole and leaf explant cultures and petiole-derived embryogenic cell suspension cultures of Hylomecon vernalis. Plant Cell Tiss. Organ Cult. 74(2), 163167.

Kintzios, S., Nikolaou, A., Skoula, 1999. Somatic embryogenesis and in vitro rosmarinic acid accumulation in Salvia officinalis and S. fruticosa leaf callus cultures. Plant Cell Rep. 18, 462-466.

Mao, A.H., Wetten, A., Fay, M., Caligari, P.D.S., 1995. In vitro propagation of Clerodendrum colebrookianum Walp.: A potential natural antihypertension medicinal plant. Plant Cell Rep. 14, 493-496.

Misra, M., 1996. Regeneration of patchouli (Pogostemon cablin Benth.) plants from leaf and node callus, and evaluation after growth in the field. Plant Cell Rep. 15, 991-994.

Murashige, T., Skoog, F., 1962. A revised medium for rapid growth and bioassays with tabacco tissue cultures. Physiol. Plant. 15, 473-479.

Pattnaik, S., Chand, P.K., 1999. In vitro propagation of the medicinal herbs Ocimum americanum L. syn. $O$. canum Sims. (Hoary basil) and Ocimum sanctum L. (holy basil). Plant Cell Rep. 15, 846-850.

Phippen, W.B., Simon, J.E., 2000. Shoot regeneration of young leaf explants from basil (Ocimum basilicum L.). In Vitro Cell. Dev. Biol.-Plant. 36(4), 250-254.

Pola, S. R., Sarada Mani, N., 2006. Somatic embryogenesis and plantlet regeneration in Sorghum bicolour (L) Moench, from leaf segments. J. Cell Mol. Biol. 5, 99-107.

Reddy, P. S., Rodrigues, R., Rajasekharan, R., 2001. Shoot organogenesis and mass propagation of Coleus forskohlii from leaf derived callus. Plant Cell 
Tiss. Organ Cult. 66(3), 183-188.

Sahoo, Y., Pattnaik, S. K., Chand, P. K., 1997. In vitro clonal propagation of an aromatic medicinal herb Ocimum basilicum L. (sweet basil) by axillary shoot proliferation. In Vitro Cell. Dev. Biol.-Plant. 33, 293-296.

Sharzad, A., Siddiqui, S.A., 2000. In vitro organogenesis in Ocimum sanctum L. - A multipurpose herb. Phytomorphol. 50(1), 27-35.

Singh, N.K., Sehgal, C.B., 1999. Micropropagation of 'Holy Basil' (Ocimum sanctum Linn.) from young inflorescences of mature plants. Plant Growth Regul. 29(3), 161-166.
Sugimura, Y., Kadotani, N., Ueda, Y., Shima, K., Kitajima, S., Furusawa, T., Ikegami, M., 2005. Transgenic patchouli plants produced by Agrobacterium-mediated transformation, Plant Cell Tiss. Organ Cult. 82(3), 251-257.

Tokuhara, K., Mii, M., 2001. Induction of embryogenic callus and cell suspension culture from shoot tips excised from flower stalk buds of Phalaenopsis (Orchidaceae). In Vitro Cell. Dev. Biol.-Plant 37, 457-461.

Xiao, He, H., Xu, H., 2001. Study on the tissue culture and plant regeneration of Pogostemon cablin, Zhong Yao Cai. 2, 391-392.

\section{How to cite this article:}

Gopi, C., 2017. High frequency of plant regeneration through adventitious shoots proliferation from leaf explant of patchouli-Pogostemon cablin (Blanco) Benth. Int. J. Curr. Res. Biosci. Plant Biol. 4(7), 134-139. doi: https://doi.org/10.20546/ijcrbp.2017.407.017 